\section{Lateral Orbitotomy Approach to Orbital Tumors: Report of 10 Cases}

\section{Orbita Tümörlerinde Lateral Orbitotomi: 10 Olgu Sunumu}

\begin{abstract}
AIM: Lateral orbitotomy is a well-known approach for lesions of the lateral orbital cone. It is still appropriate for laterally situated tumors although contemporary cranial base approaches were defined and developed within the last decades.

MATERIAL and METHODS: Here we report 10 orbital lesions operated with lateral orbitotomy, nine of which were extraconal. Cholesterol granuloma, arachnoid cyst, pleomorphic adenoma, malign epithelial tumor, dermoid cyst, inflammatory granuloma and cavernoma were the pathologies encountered.

RESULTS: The extent of lateral orbitotomy should depend on the size, consistency and nature of the lesion for easy removal and less bony resection. In this regard, contrast enhanced CT scans give useful information for operative strategy. The success of surgery can be improved and cosmetic problems can be minimized if meticulous care is taken during orbital rim resection.

CONCLUSION: Although there is a wide range of histopathological diagnosis for orbital tumors, lateral orbitotomy is a safe approach, particularly if the lesions are extraconal.
\end{abstract}

KEYWORDS: Arachnoid cyst, Cholesterol granuloma, Extraconal, Lateral orbitotomy, Orbital tumor

\section{ÖZ}

AMAÇ: Lateral orbitotomi lateral orbita yerleşimli lezyonlar için iyi bilinen bir yaklaşımdır. Kaide tümörlerine yönelik güncel yaklaşımlar son yıllarda oldukça iyi tanımlanmış olsa da lateral orbitotomi yaklaşımı halen önemini korumaktadır.

YÖNTEM ve GEREÇ: Bu makalede 9'u ekstrakonal yerleşimli olan ve lateral orbitotomi ile ameliyat edilen 10 olgu sunulmaktadir. Kaydedilen patolojiler kolesterol granülomu, araknoid kist, pleomorfik adenom, malign epitelyal tümor, dermoid kist, enflamatuar granülom ve kavernomdur.

BULGULAR: Lateral orbitotominin sınırı lezyonun boyutu, kıvamı ve natürü ile ilişkili olacak şekilde planlanmalı ve böylece eksizyon kolay bir şekilde ve daha az kemik rezeksiyonu ile yapılmalıdır. Bu anlamda kontrastlı BT görüntüleri operatif planlama için oldukça yararlı bilgiler sunmaktadır. Özellikle orbital rimin rezeksiyonu sırasında dikkatli olunduğu takdirde, cerrahi başarı oranı yükselirken kozmetik problemler minimale indirgenir.

SONUÇ: Orbital tümörlerin histopatolojik tanısı için geniş bir tanı spektrumu olmakla birlikte, lateral orbitotomi özellikle ekstrakonal lezyonlarda güvenli bir yaklaşımdır.

ANAHTAR SÖZCÜKLER: Araknoid kist, Kolesterol granülomu, Ekstrakonal, Lateral orbitotomi, Orbital tümör
Onder OKAY

Ergun DAGLIOGLU

Gokhan AKDEMIR

Ali DALGIC

Ozhan UCKUN

Serkan ATASOY

Deniz BELEN

Ankara Numune Education and Research Hospital, Neurosurgery Department, Ankara, Turkey

Received : 14.09.2009

Accepted : 13.11.2009

Correspondence address:

Onder OKAY

E-mail : onderokay@gmail.com 


\section{INTRODUCTION}

The basic and conventional approach to superolateral orbital lesions is lateral orbitotomy (1, $3,4,7,9,17)$. The success of the surgical approach usually depends on whether a secure surgical corridor within the orbital cone is provided or not. Besides, the success of surgery also depends on the size and nature of the lesion as well as the experience and familiarity of the neurosurgeon to the orbital anatomy. The choice of the surgical approach for orbital lesions should also depend on its spatial localization with respect to orbital cone. Demarcations of the tumor and exact anatomical orientation with respect to orbital cone could aid in the selection of appropriate surgical approach. Morbidity is slightly greater for intraconal lesions when compared to extraconal ones. Intraconal lesions of the orbit usually necessitate transcranial approaches although some intraconal and laterally situated lesions could be removed effectively via lateral orbitotomy (19). Here we report 10 orbital lesions resected with lateral orbitotomy approach nine of which were extraconal.

\section{PATIENTS and METHODS}

Ten cases operated with lateral orbitotomy were selected among the cases with orbital tumors admitted to Ankara Numune Education and Research Hospital between the years 2003 and 2007. Five patients were male and 5 were female. The mean age of the patients was calculated as 42 years. Most of the patients presented with proptosis $(9 / 10)$. Nine lesions were extraconal and only one intraconal lesion was operated with the lateral orbitotomy approach and diagnosed to be a cavernoma. Histopathological diagnosis of the remaining 9 patients was pleomorphic adenoma ( 3 cases), dermoid cyst (2 cases), inflammatory granuloma (1 case), malign epithelial tumor (1 case), arachnoid cyst (1 case) and cholesterol granuloma (1 case) in decreasing order of frequency. Details of patient characteristics were summarized on Table I.

\section{DEMONSTRATIVE CASES}

\section{Case 7}

A 63-year old female patient was admitted with symptoms of swelling in the right eye for 10 months. Cranial CT and MRI revealed a laterally situated solid tumor. The lesion shows marked heterogeneous enhancement on T1-weighted MR image (Figure 1A) and diffuse enhancement on CT (Figure 1B). The lesion was hypointense on T2weighted images (Figure 1C). The patient was operated with lateral orbitotomy with minimal orbital rim osteotomy. The lesion was extraconal, very firm and partly calcified so it was removed in several pieces. Early postoperative CT image shows complete removal (Figure 1D). The postoperative course was uneventful and the patient was discharged 3 days after the operation. Histopathological diagnosis was compatible with pleomorphic adenoma.

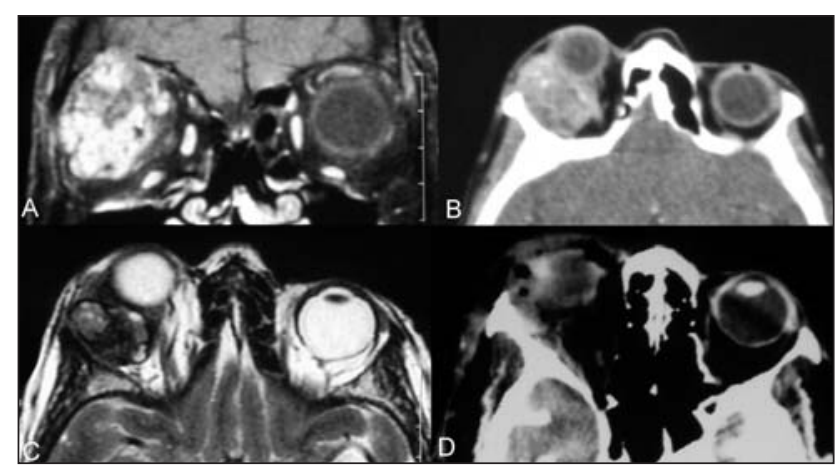

Figure 1: A. Preoperative T1-weighted MR image showed heterogeneous gadolinium enhancement of a huge orbital tumor, B. The tumor also had enhancement on axial CT scan, C. Axial T2-weighted MR image showed hypointense signal, D. Postoperative axial CT scan demonstrating complete removal of the extraconal posterolateral tumor which was a pleomorphic adenoma.

\section{Case 8}

A 48-year-old female was admitted with swelling on the left eye and discharge of fluid from the operative incision to the lateral orbital region. She had been operated at another center for arachnoid cyst two years ago. On CT scans she had a cystic cavity extending from the orbit to the deep temporal region (Figure 2A). The greater wing of sphenoid bone showed marked erosion. On MRI the lesion showed typical characteristics of temporal fossa arachnoid cyst extending into the orbital cavity (Figure 2B). She was operated with lateral orbitotomy to excise the cystic expansion in the orbital cavity. A dural defect extending to the posterior orbital wall was also repaired. CT scan at the postoperative period demonstrated complete excision of the cyst (Figure 2C). The postoperative course was uneventful and the patient was discharged without any complication. 


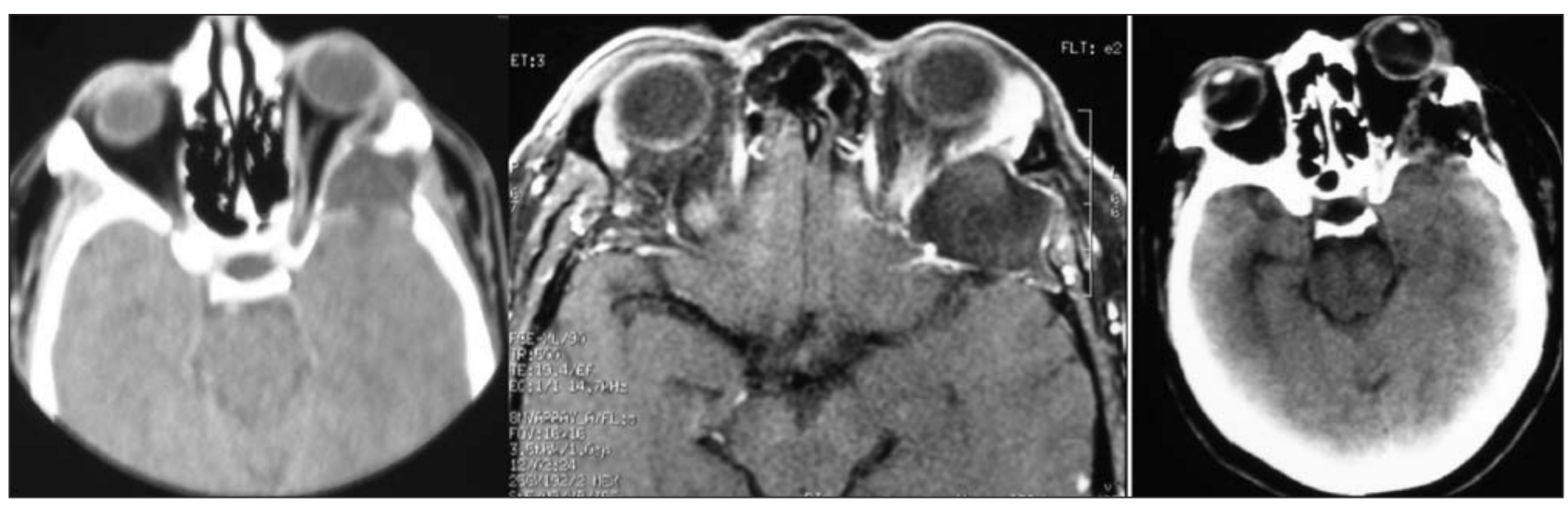

Figure 2: A. Preoperative axial CT scan showed marked erosion over the greater wing of left sphenoid bone due to temporal arachnoid cyst, B. Gadolinium enhanced axial T1-weighted MR image revealed minimal peripheral rim enhancement, C. Postoperative axial CT scan showed the lodge after removal.

Table I: Clinical Data, Radiological and Histopathological Characteristics of 10 Patients Operated with Lateral Orbitotomy.

\begin{tabular}{|c|c|c|c|c|c|c|c|c|c|}
\hline $\begin{array}{l}\text { Case } \\
\text { No }\end{array}$ & Age & Sex & History & Symptoms & Duration & $\begin{array}{l}\text { Neurological } \\
\text { Findings }\end{array}$ & $\begin{array}{l}\mathrm{CT} \text { and MRI } \\
\text { characteristics }\end{array}$ & $\begin{array}{c}\text { Histopathological } \\
\text { Diagnosis }\end{array}$ & $\begin{array}{l}\text { Complications } \\
\text { and Outcome }\end{array}$ \\
\hline 1 & 15 & $\mathrm{M}$ & $\begin{array}{l}\text { Herpetic } \\
\text { keratitis }\end{array}$ & Proptosis & 4 years & $\begin{array}{c}\text { Exophthalmos, } \\
\text { ptosis }\end{array}$ & $\begin{array}{l}2 \times 2 \times 1.5 \mathrm{~cm}, \\
\text { solid, } \\
\text { extraconal }\end{array}$ & $\begin{array}{c}\text { Inflammatory } \\
\text { process, } \\
\text { granuloma }\end{array}$ & Excellent \\
\hline 2 & 43 & $\mathrm{~F}$ & - & Proptosis & 6 months & Exophthalmos & $\begin{array}{l}2.5 \times 2 \times 2 \mathrm{~cm}, \\
\text { solid, } \\
\text { extraconal }\end{array}$ & Dermoid cyst & $\begin{array}{l}\text { Wound CSF } \\
\text { fistula } \\
\text { completely } \\
\text { resolved with } \\
\text { lumbar drainage }\end{array}$ \\
\hline 3 & 46 & $\mathrm{M}$ & - & Headache & 1 year & Normal & $\begin{array}{l}2 \times 2 \times 2 \mathrm{~cm}, \\
\text { solid, } \\
\text { intraconal }\end{array}$ & Cavernoma & $\begin{array}{l}\text { Transient } 4 \text { th } \\
\text { nerve paresis }\end{array}$ \\
\hline 4 & 44 & M & - & Proptosis & 6 months & Exophthalmos & $\begin{array}{c}2 \times 2 \times x 2.5 \mathrm{~cm}, \\
\text { solid, } \\
\text { extraconal }\end{array}$ & $\begin{array}{l}\text { Pleomorphic } \\
\text { adenoma }\end{array}$ & Excellent \\
\hline 5 & 57 & $\mathrm{~F}$ & $\begin{array}{c}\text { Operated } \\
\text { previously for } \\
\text { orbital mass }\end{array}$ & $\begin{array}{l}\text { Proptosis, } \\
\text { ptosis, pain }\end{array}$ & 7 months & $\begin{array}{c}\text { Ptosis, } \\
\text { exophthalmos }\end{array}$ & $\begin{array}{l}2 \times 1.5 \times 1 \mathrm{~cm}, \\
\text { solid, } \\
\text { extraconal }\end{array}$ & $\begin{array}{l}\text { Pleomorphic } \\
\text { adenoma }\end{array}$ & Excellent \\
\hline 6 & 32 & $\mathrm{M}$ & - & $\begin{array}{l}\text { Proptosis, } \\
\text { pain }\end{array}$ & 8 months & Exophthalmos & $\begin{array}{l}7 \times 5.5 \times 5 \mathrm{~cm}, \\
\text { extraconal, } \\
\text { bone erosion }\end{array}$ & $\begin{array}{l}\text { Malign epithelial } \\
\text { tumor }\end{array}$ & $\begin{array}{l}\text { Conjunctival } \\
\text { chemosis which } \\
\text { improved with } \\
\text { medical } \\
\text { treatment }\end{array}$ \\
\hline 7 & 63 & $\mathrm{~F}$ & - & Proptosis & 10 months & Exophthalmos & 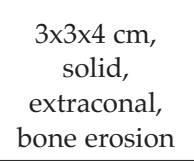 & $\begin{array}{l}\text { Pleomorphic } \\
\text { adenoma }\end{array}$ & Excellent \\
\hline 8 & 48 & $\mathrm{~F}$ & $\begin{array}{c}\text { Operated } \\
\text { previously for } \\
\text { orbital } \\
\text { arachnoid cyst }\end{array}$ & $\begin{array}{l}\text { Headache, } \\
\text { proptosis, }\end{array}$ & 2 months & Exophthalmos & $\begin{array}{c}4 \times 3 \times 3.5 \mathrm{~cm}, \\
\text { cystic, } \\
\text { extraconal }\end{array}$ & Arachnoid cyst & Excellent \\
\hline 9 & 50 & M & - & $\begin{array}{l}\text { Proptosis, } \\
\text { blurring of } \\
\text { vision }\end{array}$ & 1 month & Exophthalmos & $\begin{array}{l}2 \times 2.5 \times 2 \mathrm{~cm} \\
\text { solid, } \\
\text { extraconal }\end{array}$ & $\begin{array}{l}\text { Cholesterol } \\
\text { granuloma }\end{array}$ & Excellent \\
\hline 10 & 25 & $\mathrm{~F}$ & - & Proptosis & 6 months & Exophthalmos & $\begin{array}{l}3 \times 2.5 \mathrm{~cm}, \\
\text { cystic, } \\
\text { extraconal }\end{array}$ & Dermoid cyst & Excellent \\
\hline
\end{tabular}




\section{Case 9}

A 50-year-old male was admitted with symptoms of blurring of vision and orbital swelling on the left eye for one month. He had overt exophthalmos on physical examination but the neurological examination including visual acuity was completely normal. On MRI, he had an extraconal tumor which was $2 \times 2.5 \times 2$ centimeters in size (Figure $3 \mathrm{~A}, \mathrm{~B}$ ). The lesion showed marked contrast enhancement on T1weighted coronal images (Figure 3A). The lesion had a marked hypointense part on T2-weighted MR image (Figure 3B). Marked bony erosion of the orbital roof was noted on CT scans with marked enhancement (Figure 3C). The patient was operated via lateral orbitotomy and yellow-white cystic mass was removed completely. Histopathological diagnosis confirmed cholesterol granuloma and there was no residual mass on postoperative gadolinium enhanced T1-weighted images (Figure 3D).

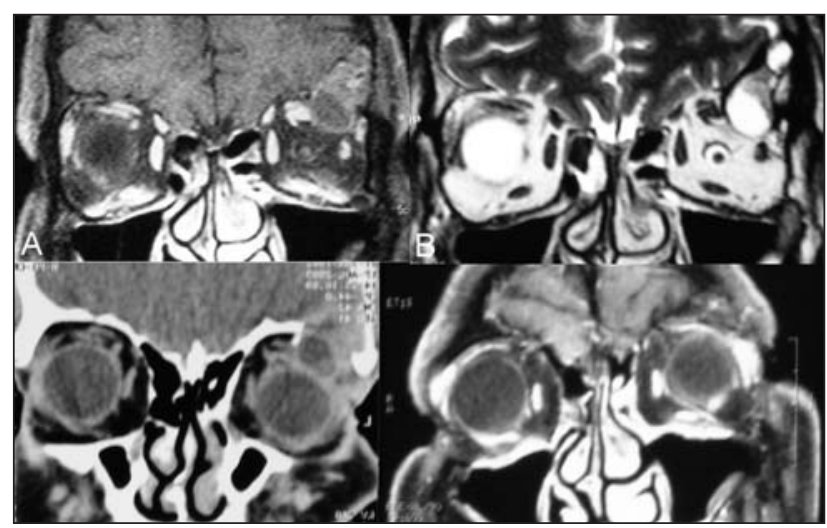

Figure 3: A. Preoperative T1-weighted MR image showed heterogeneous gadolinium enhancement of a tumor to the superolateral region of left orbita, B. T2-weighted $M R$ image demonstrated a region of marked hyperintensity, C. CT scan revealed marked bony erosion of the superolateral region of the orbit, D. Postoperative coronal T1-weighted gadolinium enhanced image demonstrated complete removal of cholesterol granulama.

\section{DISCUSSION}

Lateral orbitotomy is one of the most common extraorbital approaches to superolateral orbital lesions. The approach is not limited to laterallysituated lacrimal gland tumors and provides removal of superior or posterior tumors even if they are large. The exact choice of approach depends on tumor size, localization, consistency or nature of the lesion but we consider that the most important factor is the localization with respect to the orbital cone.

Advancements in neurosurgical techniques and anterior skull base approaches encourage us to perform a transcranial orbital approach with a considerable morbidity which is usually related to the orbital pathology not the technique (12). Orbital lesions could be removed with minimal cerebral retraction and relatively few problems like CSF fistulas. There are very few complications related to cerebral injury or dural laceration. Nevertheless, complications like decrease in visual acuity, diplopia, gaze paresis and enophthalmos could develop more after transcranial approaches $(9,19,22)$. Extension of the tumor to the medial site of the frontozygomatic suture would certainly necessitate transcranial approaches (frontoorbital or frontoorbitozygomatic). However, lateral orbitotomy provides a wide surgical field in the orbit while providing an efficient access to superolateral cone $(1,7,13,17)$. Lesions located superior, lateral and inferior to the orbital cone could be removed best via lateral orbitotomy. The orbital rim could be removed from the origin of supraorbital nerve (supraorbital notch) to the attachment of zygomatic arch without any complication since there are no neural or vascular attachments to the rim. Extent of rim removal or addition of bone removal from the posterolateral cone should be determined according to lesion size and position with respect to orbital rim and cone. Consistency of the tumor is also an important parameter since tough and calcified lesions may necessitate a wider orbital osteotomy. This rim removal strategy also helps to decrease the cosmetic problems related to skin incision length and bone removal. On the other hand, safe retraction of the orbital cone in extraconal tumors of the orbit provides safer removal with an acceptable morbidity. Nevertheless, intraconal orbital tumors with well-demarcated margins and lateral localization may be removed with lateral orbitotomy (1). Removal of bone could be minimized to perform a successful operation if the preoperative images are carefully reviewed for a presence of bone erosion on CT scans.

Although most orbital lesions are benign, their diagnosis is a particular challenge unless a biopsy or surgery is performed. In fact, orbital tumors constitute a wide spectrum of histopathological 
origin. Apart from malignant lesions like hemangiopericytoma or lymphoma, some vascular malformations like cavernous hemangioma or congenital lesions like dermoid cyst or sometimes metastatic lesions could be encountered in the orbit $(5,12,17)$. A broad category of inflammatory diseases pose a special diagnostic problem. Whether it is lymphoid, granulamotous or sclerosing subtype, an orbital pseudotumor could simulate the signs and symptoms of an orbital tumor (14). On the other hand, osteoma, some metastatic lesions of the orbit, or sometimes pleomorhic adenomas and pseudotumors of the orbit could have a cartilageneous or calcified capsule which makes the removal complicated. Regardless of the tumor histopathology, lateral orbitotomy is a safe approach with less morbidity for laterally situated lesions (1, 9). Nevertheless, orbital tumors with invasive radiological features, particularly if located intraconally, are more appropriate for transcranial approaches since lateral orbitotomy is associated with increased morbidity compared to transcranial approaches. Lesions with invasive behavior and malignant characteristics are accepted as candidates for transcranial approaches. Nevertheless, the choice of approach also depends on the surgeon's preference.

Arachnoid cysts are congenital lesions that are most frequently localized in the middle cranial fossa. Middle fossa arachnoid cysts have an anatomical proximity to the orbita and have a potential to cause significant proptosis due to bone remodeling of orbital walls $(6,23)$. Pure intraorbital arachnoid cysts were reported to have an anatomical relation with the optic nerve $(15,18)$. Arachnoid cyst reported in the present series was demonstrated to erode the sphenoid bone and severe headache due to pulsatile exophthalmos. The cyst membrane should be ruptured or removed in order to decrease the tension and thus pulsatile headache. The lesion was approached with lateral orbitotomy since the bony margin adjacent to the orbital wall has already been eroded with the cyst.

Orbital cholesterol granulomas are uncommon orbital lesions usually localized in the superolateral cone $(10,11,16)$. Some patients with cholesterol granulomas were reported to have a history of trauma. These tumors can compress or invade adjacent anatomical structures. The frontal bone or frontal sinus can easily be involved by a cholesterol granuloma $(2,20,21)$. Thus CT examination shows bony destruction with a soft tissue mass same as the density of brain extending extraperiosteally into the orbit and these lesions should be differentiated from dermoid tumors of the orbit. (8). Cholesterol granulomas are benign and lack an epithelial lining which is the most important feature to differentiate from cholesteatoma (11). The case we reported in the present series shows radiological features that could not be easily differentiated from a dermoid tumor. Lateral orbitotomy is quite appropriate for the excision of these tumors since they are usually confined to the superolateral cone and are soft in consistency. Thus, lateral orbitotomy is a satisfactory approach for lateral and superior extraconal lesions. The surgical corridor provided by frontoorbital approach is not wider than lateral orbitotomy for superolateral lesions of the orbit, particularly if extraconal.

\section{CONCLUSION}

Advancements in microsurgical techniques and standard use of orbitozygomatic craniotomy for various lesions of the cranial base provided the neurosurgeons being more familiar to orbital anatomy. Nevertheless, lateral orbitotomy is still an appropriate, safe and less time-consuming procedure for lateral extraconal lesions of the orbit.

\section{REFERENCES}

1. Arai H, Sato K, Katsuta $\mathrm{T}$, Rhoton A: Lateral approach to intraorbital lesions: Anatomic and surgical considerations. Neurosurgery 39: 1157-1163, 1996

2. Arat YO, Chaudhry IA, Boniuk M: Orbitofrontal cholesterol granuloma: Distinct diagnostic features and management. Ophthal Plast Reconstr Surg 19: 382-387, 2003

3. Bejjani GK, Cockerham KP, Kennerdell JS, Maroon JC: Surgery for orbital tumors. Part II: Transorbital approaches. Neurosurg Focus 10: E3, 2001

4. Carta F, Siccardi D, Cossu M, Viola C, Maiello M: Removal of tumours of the orbital apex via a postero-lateral orbitotomy. J Neurosurg Sci 42: 185-188, 1998

5. Darsaut TE, Lanzino G, Lopes MB, Newman S: An introductory overview of orbital tumors. Neurosurg Focus 10: E1, 2001

6. Fisher T, Nugent R, Rootman J: Arachnoid cysts with orbital bone remodeling--two interesting cases. Orbit 24: 59-62, 2005

7. Gonul E, Timurkaynak E: Lateral approach to orbit: An anatomical study. Neurosurg Rev 21: 111-116, 1998

8. Hill CA, Moseley IF: Imaging of orbitofrontal cholesterol granuloma. Clin Radiol 46: 237-242, 1992

9. Kang JK, Lee IW, Jeun SS, Choi YK, Jung CK, Yang JH, Kim DS: Tumors of the orbit. Pitfalls of the surgical approach in 37 children with orbital tumor. Child Nerv Syst 13: 536-541, 1997 
10. Karim MM, Inoue $M$, Hayashi $Y$, Nishizaki $M$, Hanioka $K$, Imai $\mathrm{Y}$, Ito $\mathrm{H}$, Yamamoto $\mathrm{M}$ : Orbital cholesterol granuloma with destruction of the lateral orbital roof. Jpn J Ophthalmol 44: 179-182, 2000

11. Loeffler KU, Kommerell G: Cholesterol granuloma of the orbit--pathogenesis and surgical management. Int Ophthalmol 21: 93-98, 1997

12. Margalit N, Ezer H, Fliss DM, Naftaliev E, Nosek E, Kesler A: Orbital tumors treated using transcranial approaches: surgical technique and neuroophthalmogical results in 41 patients. Neurosurg Focus 23: E1, 2007

13. Maroon JC, Kennerdell JS: Surgical approaches to the orbit. Indications and techniques. J Neurosurg 60: 1226-1235, 1984

14. McNicholas MM, Power WJ, Griffin JF: Idiopathic inflammatory pseudotumour of the orbit: CT features correlated with clinical outcome. Clin Radiol 44: 3-7, 1991

15. Moschos MM, Lymberopoulos C, Moschos M: Arachnoid cyst of the optic nerve: A case report. Klin Monatsbl Augenheilkd 221: 408-409, 2004

16. Ong LY, McNab AA: Recurrent orbital cholesterol granuloma. Orbit 27: 119-121, 2008

17. Paolini S, Santoro A, Missori P, Pichierri A, Esposito V, Ciappetta P: Surgical exposure of lateral orbital lesions using a coronal scalp flap and lateral orbitozygomatic approach: Clinical experience. Acta Neurochir (Wien) 2006; 148 (9): 959-963
18. Saari M, Mustonen E, Palva A, Jokinen K, Reunanen M: Arachnoid cyst of the intraorbital portion of the optic nerve with unilateral disc oedema and transient shallowing of the anterior chamber. A case report. Acta Ophthalmol (Copenh) 55: 959-964,1977

19. Schick U, Dott U, Hassler W: Surgical Treatment of orbital cavernomas. Surg Neurol 60: 234-244, 2003

20. Selva D, Chen C: Endoscopic approach to orbitofrontal cholesterol granuloma. Orbit 23: 49-52, 2004

21. Shykhon ME, Trotter MI, Morgan DW, Reuser TT, Henderson MJ: Cholesterol granuloma of the frontal sinus. J Laryngol Otol 116: 1041-1043, 2002

22. Stefanyszn MA, Handler SD, Wright JE: Pediatric orbital tumors. Otolaryngol Clin North Am 21: 103-118, 1988

23. Tsitouridis I, Papastergiou C, Emmanouilidou M, Goutsaridou F, Chondromatidou S, Eleni T: Arachnoid cyst of the frontal part of the temporal lobe producing exopthtalmos CT and MRI evaluation. Clin Imaging 26: 302-305, 2002 